\title{
Use and Misuse of Prepositions among EFL Secondary School Students
}

\author{
Wasil Hassan M. A. Elaagip \\ Assistant Professor, Department of English Language, College of Science and Arts, Tanumah, King Khalid University - Saudi \\ Arabia
}

\author{
Wasil Hassan M. A. Elaagip, \\ Assistant Professor, Department of English Language, College of Languages, University of Bahri - SUDAN
}

\begin{abstract}
:
This research aims at focusing on use and misuse of prepositions among the secondary school students who learn English as a foreign language. Students need balanced efforts and conditions to familiarize themselves with using prepositions properly. This research includes an experimental survey to reveal the causes of this problem as it affects hugely on the general knowledge of the students and their use of the language in writing or comprehension. The paper consists of four parts: the first part discusses the objectives, significance of the study, background questions and the methods used in building up this research. In part two, there is a review of the literature and many other ideas about definition, types and uses of prepositions and its roles in the field of language knowledge. Part three includes the survey findings, discussion, results as well as analysis of the test. In part four, there is conclusions and recommendations.
\end{abstract}

Keywords:

Prepositional Phrases, Coordinating Conjunctions, Correlative Conjunctions, Subordinating Conjunctions.

\section{Introduction}

\subsection{Background:}

A preposition is a word, or a group of words used before nouns, pronouns or noun phrases. Preposition also shows the relation of a noun or a pronoun or a noun phase or clause to the rest of a sentence. However, there are sometimes many simple words and groups of words which act as prepositions and as a result many users of English as a foreign language may fall in the mistake by misusing prepositions. This can easily be explained by the fact that some prepositions in English Language are idiomatic or the fact that the use of preposition varies from one language to another.

\subsection{Research Problem:}

The correct use of prepositions is a problem faced by both teachers and students. At the time when some students are confused with the use of prepositions in their first language and the target language; others have problems in the identification of prepositions.

\subsection{Research Objectives:}

The main objective of this research is to show how the use of prepositions posits problems to students at secondary school. It also attracts attention to the use of the different types of prepositions.

\subsection{Research Questions:}

This research has the following questions:

- What are the kinds of prepositions?

- How are prepositions used in a language?

\subsection{Research Hypotheses:}

The research has the following hypotheses:

1- Students are not well acquainted with types and uses of prepositions.

2- It is not easy for students to differentiate between prepositions and the other parts of speech.

3- Prepositions is one of the least well-known parts of speech for the students.

\subsection{Research Significance:}


There is a misuse of prepositions among secondary school students. They make many different mistakes like putting a preposition in the wrong place. Prepositions make up a very important part of language without which we may not communicate appropriately.

\subsection{Methodology of Research:}

Descriptive and analytical methods are applied for this research. Some students are randomly selected from some secondary schools.

\subsection{Limitation of Study:}

About sixty secondary school students were selected from three schools in Khartoum State, Sudan.

\section{Literature Review:}

\subsection{Previous Studies:}

The main topic of this research is the appropriate use of prepositions. The researcher tackles the types of prepositions together with detailed examples in addition to teaching of prepositions to EFL students.

The core of the title is to tell why the use of prepositions is problematic among secondary school students.

Prepositions are illustrated as simple and complex. (Murphy, 2007) in his book, Essential English Grammar, defines the simple preposition as just one word without giving any further definition. Complex preposition defined as a group of words consist of more than two prepositions.

\begin{tabular}{cl} 
Simple & \multicolumn{1}{c}{ Complex } \\
about & according to \\
by & for the sake of \\
of & with regard to
\end{tabular}

John E. mentions in his book that preposition affects the relationship between the word following the preposition and the word before it (John E. 1958). By changing this relationship different prepositions give each sentence different meaning.
2.1.1. Prepositional Phrases: Within a sentence, a preposition is almost followed by a noun or a pronoun.

A prepositional phrase is a group of words that includes a preposition and a noun or pronoun. The noun or pronoun generally found after the preposition is called the object of the preposition. One preposition can have two or more objects. Preposition phrase is usually two or three words long. It can however be much longer in length depending on the number of modifiers before the object of the preposition, the number of objects and the length of the preposition itself.

Table 1: A chart shows the Prepositional Phrases with two Parts.

\begin{tabular}{|c|c|}
\hline \multicolumn{2}{|c|}{ Prepositional Phrases } \\
\hline Preposition & Objects of Preposition \\
\hline for & you \\
\hline throughout & the school \\
\hline between & you and me \\
\hline
\end{tabular}

\subsubsection{Preposition with relationship in time:}

Some prepositions are used to express certain time; the time of events. If we find a question starting with when referring to time the answer must begin with preposition referring time for example:

after - before - at - since - until

Sometimes the sentences include both prepositions of place and time. The students must bear in mind that there are some prepositions that can be used with the "time" word, but with different meaning. For instance:

- On time: try to arrive on time, be punctual.

- In time: If you hurry, you should be (just) in time to catch the train; you will not be too late.

- At the time: Fred called. I was in the bath at the time. 
- At one time: At one time you could get hotel room for 5.00 dollar; there was a time where this was true.

- At time: He behaves a little strangely at times - sometimes.

\subsection{Preposition of Other Meanings:}

There are some other prepositions related to other meanings. They are discussed under some headings below.

- Prepositions of cause, reason and purpose:

The approximate meaning of cause is the effect of an event or something that happens. On the other hand, reason means the justification of something happening.

- Prepositions of exception, addition, support and opposition:

Here, we need to consider the following points:

- All children left except John = Here the preposition "except" refers to an exception.

- Apart from his inherited wealth = Here "apart from" means in addition to something.

- Our trainer was with us throughout the race $=$ Here "with us" means support.

- He is against the travel sales man's job = Here "is against" means opposition.

In addition to the aforementioned prepositions, there are some unfamiliar prepositions also. For example:

- Prepositions like: via and vis-a-vis: these are exemplified by: We came to know about your success via your sister. Here "via" refers to preposition of manner, while vis-a-vis refers to preposition of comparison.

\subsection{Preposition vs. Adverb?}

There are some words which are basically prepositions but can also be adverbs depending on how they are used in the sentence. The comparison between them are illustrated below:

A single word acting as an adverb answers where, when, how or to what degree about the verb.

- If you want to see the eclipse, you will need to go outside.

OUTSIDE tells you where YOU WILL NEED TO GO.

NOTE: Without an object OUTSIDE is an adverb.

When the same word is a preposition, the entire prepositional phrase acts as an adverb modifying the verb.

- Dorothy colors outside the lines.

OUTSIDE THE LINES is an adverbial phrase and OUTSIDE is a preposition.

NOTE: LINES is the object of the preposition.

To determine whether a word is an adverb or a preposition, look at what follows the word. Is there a noun acting as an object of the word? In other words, is there a word that answers the question WHAT? about the word.

- It will be some time before his schedule settles down.

DOWN tells the reader WHERE the schedule settles. There is no object following it.

- Please sit down and listen.

DOWN tells the listener WHERE to SIT. There is no object telling him or her WHAT to SIT DOWN.

- One need only look down the roster to see the impact of so much travel.

\subsection{Conjunctions and interjections:}

Sometimes prepositions also show relationships between words and perform as a conjunction. We know that a conjunction is a word used to connect other words or groups of words. 
In English we have three kinds of conjunctions or connecting words:

\section{a) Coordinating Conjunctions:}

There are seven coordinating conjunctions like: and, but, for, nor, or, so and yet.

Table 2: Examples of Coordinating Conjunctions.

\begin{tabular}{|l|l|}
\hline $\begin{array}{l}\text { Nouns and } \\
\text { Pronouns }\end{array}$ & Joaquin and I are good friends. \\
\hline Verbs & $\begin{array}{l}\text { Amos trembled yet continued } \\
\text { his way. }\end{array}$ \\
\hline Adverbs & $\begin{array}{l}\text { Meg chained the butter slowly } \\
\text { but skillfully. }\end{array}$ \\
\hline $\begin{array}{l}\text { Prepositional } \\
\text { phrases }\end{array}$ & $\begin{array}{l}\text { The dog ran out the door and } \\
\text { across. }\end{array}$ \\
\hline $\begin{array}{l}\text { Subordinate } \\
\text { Ideas }\end{array}$ & $\begin{array}{l}\text { Karen wrote that she was } \\
\text { enjoying London but that she } \\
\text { had caught a cold. }\end{array}$ \\
\hline Complete Ideas & $\begin{array}{l}\text { The bear slept, for winter had } \\
\text { come. }\end{array}$ \\
\hline
\end{tabular}

\section{b) Correlative Conjunctions:}

On the other hand, correlative conjunctions are like coordinating conjunctions. Correlative conjunctions are always used in pairs. For example: both, and, neither, nor, whether, or, either, not only, but also.

\section{Table 3: Examples of Correlative} Conjunctions.

\begin{tabular}{|l|l|}
\hline Nouns & $\begin{array}{l}\text { He owned neither a coal nor } \\
\text { a hat. }\end{array}$ \\
\hline Nouns-pronouns & $\begin{array}{l}\text { She asked whether I stayed } \\
\text { or I had left. }\end{array}$ \\
\hline Adjectives & $\begin{array}{l}\text { Both gold and beige carpets } \\
\text { were considered. }\end{array}$ \\
\hline $\begin{array}{l}\text { Prepositional } \\
\text { phrases }\end{array}$ & $\begin{array}{l}\text { The guilt was and shared not } \\
\text { only by him but also by us. }\end{array}$ \\
\hline Complete Ideas & $\begin{array}{l}\text { Either Brenda will attend the } \\
\text { meeting, or she is sick. }\end{array}$ \\
\hline
\end{tabular}

\section{c) Subordinating Conjunctions:}

These connects two complete ideas by making one of them subordinate to or less important than the other.

Table 4: Frequently used Subordinating Conjunctions.

\begin{tabular}{|l|l|l|l|}
\hline After & Because & Now that & Until \\
\hline Although & Before & Since & When \\
\hline As & Even if & So that & Whenever \\
\hline As if & Even though & Than & Where \\
\hline As long as & If & Though & Wherever \\
\hline
\end{tabular}

\subsection{Prepositions at the End of the Sentence:}

There are number of cases in everyday English sentences where the preposition comes at the end of the sentence. In most cases a phrasal verb of the type: "verb + preposition; the pronoun is either:

Relative: I was talking about a book. Here "the book" that I was talking about.

Interrogative: He is looking at something + what. What is he looking at?

Secondary school students may think that a preposition at the end of a sentence is a misuse or a mistake.

\subsection{Prepositional Idioms:}

Many prepositions are used with idioms. Here are few examples:

$\checkmark$ John began to argue loudly, and I thought it was time I stepped in.

$\checkmark$ She is at heart a very kind person.

$\checkmark$ He thanked us from the bottom of his heart for all our help.

It is usually problematic to distinguish between preposition idioms and other similar prepositions.

\section{Analysis and Discussion:}

\subsection{Methodology:}


Qualitative method is used for this research. A test has been designed and distributed among the students and filled under the supervision of the researcher.

\subsubsection{Subjects:}

Sixty students of second and third grades from three secondary schools in Omdurman, Khartoum and Khartoum North were selected as sample of this research.

\subsubsection{Instrument:}

The instrument for this study is a test consisting of three main questions. Question one consists of four questions and the student shall mark right or wrong. Question two consists of filling the blank space; while question three is a collection of number of words to find out which of them are the prepositions.

\subsubsection{Procedure:}

The researcher asked students about prepositions during the test. Then the test distributed among the students, they were asked to answer the questions under the monitoring of the researcher.

\subsection{Analysis, Results and Discussion:}

\subsubsection{Types of Preposition:}

Question 1 shows to how much students know about uses of prepositions. The majority answer the question in a wrong way. $70.14 \%$ said it is not possible to put a preposition at the end of a sentence, which is wrong. While $30.6 \%$ students chose a correct answer.

As for question two, $80.16 \%$ of the students chose the correct answer. It tells that they know about prepositional phrases. While $20.4 \%$ of the students selected a wrong answer.

Question three, contradicts with question two. $35.7 \%$ of the students only know about phrasal prepositions. They obviously know about prepositional phrase as a part of speech and they know that some prepositions consist of more than one word, but prepositional phrase, as a term, may not be familiar for them.

Concerning question four, we find $20.4 \%$ answered that they know phrasal idioms while the majority $80.16 \%$ said that they know nothing about it. That may indicate very little knowledge about prepositional idioms at this stage.

Table 5: Students' Recognition of Types of Preposition.

\begin{tabular}{|l|c|c|}
\hline Question & Right & Wrong \\
\hline 1- We can't put a preposition at the end of a sentence & $70.14 \%$ & $30.6 \%$ \\
\hline $\begin{array}{l}\text { 2- Some prepositions consist of more than one word or } \\
\text { more. }\end{array}$ & $80.16 \%$ & $20.4 \%$ \\
\hline 3- Some prepositions are called prepositional phrases & $35.7 \%$ & $65.13 \%$ \\
\hline 4- In English language there are prepositional idioms & $20.4 \%$ & $80.16 \%$ \\
\hline
\end{tabular}

\subsubsection{Use of prepositions:}

In this part, students were given three questions. The first one about the use of prepositions as single words. Most of the students do not know how to use prepositions properly as only $16.2 \%$ of the students answered the question correctly and $83.8 \%$ of the students answered it wrongly. The second question was concerned with the use of prepositional phrases, and also very few students (19.1\%) answered it correctly, while $80.9 \%$ answered it incorrectly.

The third question was about the use of prepositional idioms. The responses of the students to this question was not exceptional to the latter. Few students $(14.8 \%)$ answered it correctly and the majority $85.2 \%$ answered it incorrectly. 


\begin{tabular}{|l|c|c|}
\hline Question & Correct & Incorrect \\
\hline He played - football - by football. & $16.2 \%$ & $83.8 \%$ \\
\hline $\begin{array}{l}\text { They insisted - on going back - in } \\
\text { going back. }\end{array}$ & $19.1 \%$ & $80.9 \%$ \\
\hline $\begin{array}{l}\text { Soldiers stood - to their guns - } \\
\text { before their guns. }\end{array}$ & 14.8 & $85.2 \%$ \\
\hline
\end{tabular}

\subsubsection{Recognition of Prepositions:}

This part concerns with the recognition of prepositions among other parts of speech of English language. Students were given twelve words of different parts of speech, among which there were some prepositions.

The most recognized preposition was (on) with 83 $\%$ of correctness followed by (of) with $70 \%$ of correctness while the least recognized prepositions were (vis a vis) with $35 \%$ of correctness and (via) with the same percentage of correctness.

The most common prepositions are well known to the majority of the students while rare used prepositions like vis $\boldsymbol{a}$ vis are not on the same degree of recognition.

Table 7: Students' Recognition of Prepositions.

\begin{tabular}{|c|c|c|}
\hline The Word & Preposition & Not Preposition \\
\hline because & $25 \%$ & $75 \%$ \\
\hline whenever & $25 \%$ & $75 \%$ \\
\hline via & $35 \%$ & $65 \%$ \\
\hline while & $55 \%$ & $45 \%$ \\
\hline but & $40 \%$ & $60 \%$ \\
\hline of & $70 \%$ & $30 \%$ \\
\hline vis a vis & $35 \%$ & $65 \%$ \\
\hline the & $15 \%$ & $85 \%$ \\
\hline a & $5 \%$ & $95 \%$ \\
\hline yet & $60 \%$ & $40 \%$ \\
\hline said & $30 \%$ & $70 \%$ \\
\hline on & $87 \%$ & $13 \%$ \\
\hline
\end{tabular}

\subsection{Summary:}

As it has been explained previously, the use of preposition posits a big problem to the Sudanese students who learn English as foreign language. That was proved by the results of the test which was conducted in three different schools, in three different provinces within Khartoum State. The obtained results were summarized in the following:

- Students have no proper knowledge about types of prepositions.
- Concerning use of preposition, the majority of students gave incorrect answers to the questions in that part.

- Students have little ability to recognize and differentiate between commonly used prepositions and other parts of speech.

\subsection{Conclusions:}

The results obtained from this study confirm that the use of prepositions among Sudanese secondary school students is problematic. The 
difficulty of using prepositions may go back to the teaching method of the teachers who neglect prepositions as less important than nouns and verbs. Also, students need to be exposed to the different types, uses and the like of prepositions.

\subsection{Recommendations:}

Based on the analysis and conclusions, some recommendations can be offered to teachers, students and decision makers.

1- Students need to acquire proper knowledge about types of prepositions.

2- Concerning use of preposition, the majority of students gave incorrect answers to the questions in that part. Therefore, uses of preposition shall be much practiced.

3- Students need to upgrade and strengthen their little ability to recognize and differentiate between commonly used prepositions and other parts of speech.

4- The results obtained from this study confirm that the use of prepositions among Sudanese secondary school students is problematic. The difficulty of using preposition may go back to the teaching method of the teachers who neglect prepositions as less important than nouns and verbs. So, teachers shall deal with all parts of speech equally and to expose their students to wide range of linguistic situations in which different types of prepositions are used.

5- Teachers also need to deal with all parts of speech equally even if the text book they use in their teaching may lack such a technique.

6- Designing of text books shall address this type of little knowledge and shall provide the students with ample knowledge to skip such types of problems in the future.

\section{Bibliography:}

[1] Adrian. D. (1988). "Teaching English Methodology". Cambridge University Press.

[2] Anne, A. (1991), “CasseIL's Students English Grammar”, London University Press.
[3] Elnoor, Abdelrahman M. Y. (2003)

"Basics of English Grammar", Annual Report of Education Department, Ministry of Education Khartoum, Sudan.

[4] John E. \& Griffith, Francis Warriner. (1958). "English Grammar and Composition", Harcourt, Brace \& World, New York.

[5] Langendoen, Donald Terence and others. (1970). "Essentials of English Grammar", Holt, Rinehart and Winston Publishers.

[6] Michael, L. (1985). "Practical Teaching Use for Language Teaching”. Commercial Colour Press, London

[7] Khan, M. and M. D. Ansari (2019). "Security and Privacy Issue of Big Data over the Cloud Computing: A Comprehensive Analysis." International Journal of Recent Technology and Engineering (TM) 7(6s): 413-417.

[8] Raymond Murphy. (2007). "Essential English Grammar", Cambridge University Press.

[9] Seaton, Anne \& Mew , Y. H. (2007) "Basic English Grammar: for English Language Learners, Book 1", Saddleback Educational Publishing.

[10] Wren \& Martin's. (2017) "High School English Grammar \& Composition", S Chand Publishing.

[11] Khan, M. (2018). "Big Data Analytics Evaluation,(IJERCSE), vol-1." Issue-2, Feb.

[12] KHAN, M. (2019). "Big data analytics emerging trends, technology and innovations for the future business in the global market." International Journal of Scientific Research and Review 8(2): 745750.

[13] Khan, M. (2019). "Big Data: A Challenging Opportunity for Biomedical Informatics." Amity Journal of Computational Sciences (AJCS) 3(1): 5153.

[14] Khan, M., et al. (2019). "Map Reduce clustering in Incremental Big Data 5967 
processing." International Journal of Innovative Technology and Exploring Engineering (IJITEE) ISSN: 2278-3075 9(2): 4205-4211.

[15] Khan, M. and M. D. Ansari (2019). "Security and Privacy Issue of Big Data over the Cloud Computing: A Comprehensive Analysis." International Journal of Recent Technology and Engineering(TM) 7(6s): 413-417.

[16] Khan, M. and M. D. Ansari (2020). "Multi-criteria software quality model selection based on divergence measure and score function." Journal of Intelligent \& Fuzzy Systems 38(3): 3179-3188.

[17] Khan, M. and M. Ayyoob (2016). "The Scope of E-Learning in the Computer Science \& Technologies." International Journal of Computer Science Engineering and Information Technology Research (IJCSEITR) 6(6): 93-98.

[18] Khan, M. and M. Ayyoob (2017). "Computer security in the human life." International Journal of Computer Science and Engineering (IJCSE) 6(1): 35-42.

[19] KHAN, M. and M. AYYOOB (2017). "Cyber Security and Ethics on Social Media." Journal of Modern Developments in Applied Engineering \& Technology Research 1(2): 51-58.

[20] Khan, M. and M. AYYOOB (2018). "Big data analytics evaluation." International Journal of Engineering Research in Computer Science and Engineering (IJERCSE) 5(2): 25-28.

[21] Khan, M. and D. B. Kalra (2018). "AN INSPECTION ON BIG DATA COMPUTING." International Journal of Engineering \& Science Research (Special Issue/Article No-52): 326-329.

[22] Neeraj Kumar; Paresh Goyal; Gayatri Kapil; Alka Agrawal; Raees A Khan, "Flood Risk Finder for IoT based Mechanism using Fuzzy Logic", Materials Today: Proceedings, Elsevier, 2020.
[23] N. Kumar, A. Agrawal, R. A. Khan, "METHWORK: An Approach for Ranking in Research Trends with a Case Study for IoET, Recent advances in Computer Science and Communication (formerly Recent Patents on Computer Science), 2019 (Scopus).

[24] Kumar, Neeraj, Alka Agrawal, and R. A. Khan. "Cost estimation of cellularly deployed IoT-enabled network for flood detection." Iran Journal of Computer Science, issue 2, no. 1 (2019), Springer Nature: 53-64.

[25] G. Arora, A. K. Maurya, N. Kumar, A. K. Mishra, "Application of big data generated by IoT environment for HealthCare using Voice Recognition", International journal of research in engineering, IT and Social Sciences, vol.-08, issue-11, November 2018, page. 132-136.

[26] N. Kumar, A. Agrawal, R. A. Khan, "IoT based Alert Network for Flood Generated Emergencies", in 3rd IEEE conference on Research in Intelligent and Computing in Engineering (RICE-2018), at University Don Bosko, El Salvador, Central America, Online in Nov. 2018. (IEEE). 